\title{
PENDAPATAN USAHATANI MANGGA DIKAITKAN DENGAN KEMITRAAN DAN KARAKTERISTIK PETANI MANGGA (Kasus pada Petani Mangga di Kecamatan Sindang Kasih, Kabupaten Majalengka yang Bermitra dengan UD Wulan)
}

\author{
MANGO FARMING INCOME RELATED TO THE PARTNERSHIP AND \\ CHARACTERISTICS OF MANGO FARMERS \\ (Case of Mango Farmers in Sindang Kasih District, Majalengka Regency \\ in Partnership with UD Wulan)
}

\section{Elly Rasmikayati ${ }^{* 1}$, Bobby Rachmat Saefudin ${ }^{2}$, Yudistira Haikal Arisyi ${ }^{1}$, Rani Andriani Budi Kusumo ${ }^{1}$, Yayat Sukayat ${ }^{1}$}

\author{
${ }^{1}$ Fakultas Pertanian, Universitas Padjadjaran, Jl. Ry Bandung-Sumedang KM.21 Jatinangor, 45363 \\ ${ }^{2}$ Fakultas Pertanian, Ma'soem University, J1. Raya Cipacing No. 22 Jatinangor, 45363 \\ *E-mail: e.rasmikayati@unpad.ac.id \\ (Diterima 10-07-2020; Diterima 24-07-2020)
}

\begin{abstract}
ABSTRAK
Petani mangga di Kecamatan Sindang Kasih sudah melakukan kemitraan dengan UD Wulan Jaya untuk waktu yang cukup lama sehingga seharusnya sudah ada dampak yang didapatkan petani terutama terkait pendapatan usahatani mereka. Penelitian ini bertujuan untuk menganalisis keterkaitan antara pendapatan usahatani mangga petani yang melakukan kemitraan mangga dengan karakteristik petani dan persepsi petani mengenai aspek-aspek kemitraan. Penelitian ini menggunakan rancangan penelitian kuantitatif dengan melakukan survey. Teknik penerikan sampel yang digunakan adalah teknik sampling acak sederhana sedemikian sehingga didapatkan 38 responden petani yang melakukan kemitraan dengan UD Wulan Jaya. Teknik analisis data yang digunakan adalah analisis crosstabulation. Hasil penelitian didapatkan bahwa karakteristik petani yang cenderung berhubungan dengan pendapatan petani adalah usia, lama pengalaman bertani, luas lahan dan produktivitas per pohon. Sementara, aspek kemitraan cenderung berhubungan dengan pendapatan petani mangga adalah kelengkapan perencanaan, ketergantungan penentuan harga, peningkatan pendapatan, jaminan harga, mutu hasil produksi, dan penguasaan teknologi.
\end{abstract}

Kata kunci: Karakteristik petani, kemitraan, pendapatan usahatani, mangga, crosstabulation

\section{ABSTRACT}

Mango farmers in Sindang Kasih Subdistrict have been in partnership with UD Wulan Jaya for quite a long time so that there should have been an impact obtained by farmers, especially related to their farming income. This study aims to analyze the relationship between the farmers' income of mango farmers who do mango partnerships with the characteristics of farmers and farmers' perceptions about aspects of the partnership. This research uses a quantitative research design by conducting a survey. The sample withdrawal technique used is a simple random sampling technique such that it is obtained 38 farmer respondents in partnership with UD Wulan Jaya. The data analysis technique used is crosstabulation analysis. The results found that the characteristics of farmers who tend to be relate to the farmer income are age, farming experience, land area and productivity per tree. Meanwhile, the aspect of partnership tends to relate to the income of mango farmers are the completeness of planning, dependence on price determination, increase in income, price guarantee, quality of production results, and mastery of technology.

Keywords: Farmer characteristics, partnerships, farm income, mangoes, crosstabulation 


\section{PENDAHULUAN}

Mangga (Mangifera indica L.) merupakan komoditas hortikultura populer. Ada sekitar 400 varietas mangga yang ada di seluruh Indonesia. Mangga dapat dikonsumsi sebagai buah segar maupun dalam kondisi beku, diawetkan atau dikeringkan. Selain itu mangga dapat diproses menjadi jus, puree, maupun acar. Mangga matang paling baik dikonsumsi sebagai makanan penutup. Mangga sejauh ini sudah berperan sebagai sumber vitamin dan mineral, meningkatkan pendapatan petani, serta mendukung perkembangan industri dan ekspor (Supriatna, 2007).

Tabel 1. Produksi Mangga di 6 Wilayah Kabupaten di Provinsi Jawa Barat, 2016

\begin{tabular}{clc}
\hline No. & Kabupaten/Kota & Mangga (Kwintal) \\
\hline 1. & Kuningan & 129.195 \\
2. & Cirebon & 310.862 \\
3. & Majalengka & 375.293 \\
4. & Sumedang & 234.025 \\
5. & Indramayu & 906.435 \\
6. & Karawang & 195.269 \\
\hline Jawa & Barat & 2.601 .064 \\
\hline \multicolumn{2}{l}{ Sumber: }
\end{tabular}

Indonesia mengalami peningkatan permintaan buah-buahan, baik itu dari pasar lokal maupun internasional. Peningkatan permintaan dari pasar domestik disebabkan oleh peningkatan pendapatan masyarakat dan peningkatan kebutuhan nutrisi yang baik, salah satu buah yang memiliki tingkat permintaan yang tinggi adalah mangga. Hal tersebut tercermin dari jumlah produksi mangga dibanding dengan buah lainnya pada Tabel 1.

Kecamatan Sindang Kasih, merupakan salah satu sentra produksi mangga di Kabupaten Majalengka. Petani mangga di daerah tersebut sudah melakukan kemitraan dengan UD Wulan Jaya untuk waktu yang cukup lama (sejak tahun 2011) untuk menjangkau pasar modern dan ekspor. Kemitraan mangga berpengaruh meningkatkan perilaku agribisnis petani mangga karena ada bantuan modal dan jaminan pemasaran (Rasmikayati \& Saefudin, 2018). Salah satu unsur pokok kemitraan adalah prinsip saling memerlukan, saling memperkuat, dan saling menguntungkan (Hafsah, 1999).

Hasil penelitian sebelumnya oleh Rasmikayati dkk. (2020) mengenai kemitraan petani petani mangga dengan UD Wulan Jaya dinyatakan berada pada tingkat menengah (madya) di mana aspek-aspek kemitraan sudah berjalan cukup baik. Namun demikian, belum ada kajian mengenai keterkaitan kemitraan yang dilakukan petani dengan pendapatan usahatani mangganya. Disamping itu, faktor-faktor internal pada petani dan usahataninya juga dapat menentukan variasi pendapatan petani (Rasmikayati 
dkk., 2020). Berdasarkan hal tersebut, penelitian ini bertujuan untuk menganalisis hubungan antara pendapatan usahatani mangga petani mangga dengan karakteristik petani dan persepsi petani mengenai aspek-aspek kemitraan.

\section{METODE PENELITIAN}

\section{Tempat dan Waktu Penelitian}

Objek penelitian ini adalah hubungan karakteristik petani dan kemitraan petani mangga dengan UD Wulan Jaya dengan pendapatan usahataninya. Kecamatan Sindang Kasih, Kabupaten Manjalengka dipilih sebagai lokasi penelitian secara purposive berdasarkan pertimbangan banyak petani di lokasi tersebut yang sudah melakukan kemitraan dengan UD Wulan Jaya.

\section{Desain Penelitian}

Penelitian ini menggunakan desain penelitian kuantitatif dengan metode penelitian yang digunakan adalah metode penelitian survei. Metode ini juga bertujuan untuk melihat bagaimana kejadian-kejadian berlangsung pada waktu tertentu dan adakah dampak atau kaitan yang diberikan terhadap kejadian lain, dibantu dengan alat atau instrumen penelitian berupa kuesioner.

\section{Variabel Penelitian}

1) Pendapatan usahatani mangga, yaitu sejumlah uang yang diperoleh petani dari hasil usahatani mangga dan bukan dari usahatani mangga.

2) Karakteristik Petani Mangga

Karakteristik/identitas petani merupakan data-data personal yang dimiliki oleh petani/subjek penelitian atau ciri-ciri yang melekat pada individu petani yang dapat membedakannya dengan petani lainnya. Dalam penelitian ini, karakteristik petani meliputi:
a. Usia
b. Tingkat Pendidikan
c. Pengalaman Bertani mangga $=$
d. Luas lahan
e. Produktivitas mangga

3) Persepsi Petani Mangga terhadap Aspek Kemitraan Mangga dengan UD Wulan
a) Aspek kelengkapan perencanaan
b) Ketergantungan penentuan harga
c) Peningkatan pendapatan
d) Jaminan harga
e) Mutu produksi
f) Penguasaan teknologi.

\section{Teknik Penarikan Sampel}

Sampel diambil menggunakan teknik simple random sampling. Populasi responden pada penelitian ini yaitu petani 
mangga sebagai mitra aktif dari UD Wulan Jaya yang berjumlah 60 orang. Dengan tingkat presisi yang ditetapkan adalah $10 \%$, menggunakan rumus slovin, ukuran sampel $(n)$ yang diperoleh adalah sebagai berikut:

$\mathrm{n}=\frac{60}{1+60\left(0,1^{2}\right)}=38$ orang

\section{Rancangan Analisis Data}

Analisis data yang digunakan oleh peneliti bertujuan untuk memperoleh hasil penelitian yang dapat dipercaya dan mampu memberikan jawaban atas pertanyaan penelitian. Selain itu, analisis data perlu dilakukan untuk menarik kesimpulan berdasarkan data yang dihimpun dari hasil penelitian dengan cara membandingkan antara data yang diperoleh dari lapangan dengan data kepustakaan. Metode analisis data yang digunakan untuk menjawab, pertanyaan dalam penelitian ini adalah analisis crosstabulation.

\section{HASIL DAN PEMBAHASAN}

\section{Hubungan Karakteristik Petani dengan Pendapatan Petani Mangga}

Karakteristik petani mangga yang mempengaruhi pendapatan meliputi usia petani, pendidikan, pengetahuan, pengalaman, keterampilan, jumlah tenaga kerja keluarga, luas lahan dan modal
(Suratiyah, 2015). Menurut Soetriono et al (2014), faktor-faktor sosial ekonomi yang berpengaruh terhadap tingkat pendapatan petani, yakni usia, pendidikan, dan jumlah keluarga. Faktor lain pun seperti faktor biaya produksi, harga jual produk, jumlah produk yang dihasilkan dan sistem kerjasama. Karakteristik petani menjadi faktor internal tersendiri yang mempengaruhi pendapatan. Karakteristik yang memiliki hubungan signifikan dengan pendapatan dalam penelitian ini yaitu usia, pengalaman bertani, luas lahan, dan produktivitas petani.

Tabel 2. Tabulasi Silang Karakteristik Petani Berdasarkan Usia terhadap Kategori Tingkat Pendapatan

\begin{tabular}{|c|c|c|c|c|}
\hline & Kate & gori Ting & & \\
\hline Kategori & & ndapataı & & Jumlah \\
\hline Usia (Tahun) & $\begin{array}{c}\text { Rendah } \\
(\%)\end{array}$ & $\begin{array}{c}\text { Sedang } \\
(\%)\end{array}$ & $\begin{array}{c}\text { Tinggi } \\
(\%)\end{array}$ & $(\%)$ \\
\hline $31-45$ & 10 & 8 & 5 & 23 \\
\hline $46-64$ & 13 & 33 & 18 & 64 \\
\hline$\geq 65$ & 3 & 10 & 0 & 13 \\
\hline Jumlah & 26 & 51 & 23 & 100 \\
\hline $\begin{aligned} & \text { Ket: } \text { Tingk } \\
& \text { per } m \\
& \text { Juta } 1 \\
& \text { musin }\end{aligned}$ & $\begin{array}{l}\text { endape } \\
\text { a); } \mathrm{Se} \\
\text { nusim }\end{array}$ & $\begin{array}{l}n=\mathrm{Re} \\
\mathrm{ng}(\mathrm{Rp} \\
\text { Tinggi }\end{array}$ & ah $(<$ & $\begin{array}{l}11 \text { juta } \\
\text { Rp } 32\end{array}$ \\
\hline
\end{tabular}

Usia produktif petani adalah 15-64 tahun (BPS, 2012). Petani dengan usia tersebut seharusnya dapat menghasilkan hasil produksi lebih banyak dibanding dengan kategori usia lainnya. Ketika petani dapat menghasilkan hasil produksi lebih pada usia produktif, maka 
pendapatannya pun seharusnya lebih besar dibanding dengan kategori usia lainnya (Rasmikayati dkk., 2017). Pada kasus ini, adanya petani dengan kategori tidak produktif $(\geq 65)$, untuk melihat perbedaan pendapatan antara kategori usia yang ada dan keterkaitan pendapatan dengan kategori usia yang ada, maka dibuatlah tabulasi silang antara keduanya.

Tabel 3. Tabulasi Silang Karakteristik Petani Berdasarkan Tingkat Pendidikan terhadap Kategori Tingkat Pendapatan

\begin{tabular}{ccccc}
\hline \multirow{3}{*}{$\begin{array}{c}\text { Tingkat } \\
\text { Pendidikan }\end{array}$} & \multicolumn{3}{c}{ Pendapatan } & Jumlah \\
\cline { 2 - 4 } & $\begin{array}{c}\text { Rendah } \\
(\%)\end{array}$ & $\begin{array}{c}\text { Sedang } \\
(\%)\end{array}$ & $\begin{array}{c}\text { Tinggi } \\
(\%)\end{array}$ & \\
\hline SD & 21 & 41 & 21 & 82 \\
SMP & 5 & 10 & 3 & 18 \\
\hline Jumlah & 26 & 51 & 23 & 100 \\
\hline Ket: Tingkat pendapatan $=$ Rendah (< Rp 11 juta \\
per musim); Sedang (Rp 11 juta - Rp 32 \\
Juta per musim); Tinggi (> Rp 32 juta per \\
musim)
\end{tabular}

Petani yang cenderung memiliki pendapatan di atas Rp 32.000.000 berada pada rentang usia 46-64 tahun, hal ini bisa merujuk kepada pengalaman bertani yang lebih lama dan kepemilikan lahan yang seiring bertambah luas ketika usia semakin bertambah, dan usia 46-64 tahun merupakan puncak usia produktif petani. Petani dengan usia di atas 65 tahun hampir semuanya berada pada kategori pendapatan $\mathrm{Rp} 11.000 .000 \quad-\mathrm{Rp}$ 32.000 .000 (Tabel 2).
Menurut BPS (2012), tingkat pendidikan petani terbilang jarang untuk menginjak jenjang yang lebih tinggi dari pada SMA, terutama untuk petani yang sudah ada pada rentang usia 45 keatas saat ini mayoritas petaninya merupakan lulusan SD dan SMP. Pendidikan menjadi salah satu karakteristik yang menarik sebagaimana yang dikatakan oleh Barret (2012) bahwa tingkat pendidikan mempengaruhi keputusan yang petani ambil hampir dalam setiap hal yang ada dalam usahatani, termasuk langkah untuk bermitra. Tentunya, keputusan-keputusan tersebut menjadi langkah strategis petani untuk salah satunya meraih pendapatan semaksimal mungkin. Namun pada kenyataannya, tingkat pendidikan tidaklah signifikan berhubungan langsung dengan tingkat pendapatan petani, sebaran persentase masing-masing jumlah petani dengan pendidikan terakhir SD dan SMP hampir sama (Tabel 3).

Pengalaman bertani menjadi faktor penting dalam melakukan usahatani mangga, maka seharusnya ada keterkaitan antara pengalaman bertani dengan pendapatannya. Realita di lapangan, mayoritas petani dengan kategori kurang berpengalaman memiliki pendapatan sebesar Rp 11.000.000 - Rp 
PENDAPATAN USAHATANI MANGGA DIKAITKAN

DENGAN KEMITRAAN DAN KARAKTERISTIK PETANI MANGGA

Elly Rasmikayati, Bobby Rachmat Saefudin, Yudistira Haikal Arisyi, Rani Andriani Budi Kusumo, Yayat Sukayat

32.000.000. Fakta ini tidak memungkiri bahwa pengalaman bertani menjadi faktor penting, kategori pendapatan tertinggi yaitu $>\operatorname{Rp} 32.000 .000$ didominasi oleh petani yang cukup berpengalaman, adapun petani yang berpengalaman hanya berjumlah 3 orang sehingga tidak bisa dinyatakan memiliki kecenderungan kategori pendapatan dibanding dengan kategori pengalaman bertani lainnya (Tabel 4).

Tabel 4. Tabulasi Silang Karakteristik Petani Berdasarkan Pengalaman Bertani terhadap Kategori Tingkat Pendapatan

\begin{tabular}{|c|c|c|c|c|}
\hline \multirow{2}{*}{$\begin{array}{c}\text { Pengalaman } \\
\text { Bertani } \\
\text { Mangga }\end{array}$} & \multicolumn{3}{|c|}{$\begin{array}{l}\text { Kategori Tingkat } \\
\text { Pendapatan }\end{array}$} & \multirow{2}{*}{$\begin{array}{c}\text { Jumlah } \\
(\%)\end{array}$} \\
\hline & $\begin{array}{c}\text { Rendah } \\
(\%)\end{array}$ & $\begin{array}{l}\text { Sedang } \\
(\%)\end{array}$ & $\begin{array}{l}\text { Tinggi } \\
(\%)\end{array}$ & \\
\hline $\begin{array}{l}\text { Kurang } \\
\text { Berpenga- } \\
\text { laman }\end{array}$ & 10 & 30 & 8 & 48 \\
\hline $\begin{array}{l}\text { Cukup } \\
\text { Berpenga- } \\
\text { laman } \\
\end{array}$ & 16 & 18 & 15 & 49 \\
\hline $\begin{array}{l}\text { Berpenga- } \\
\text { laman }\end{array}$ & 0 & 3 & 0 & 3 \\
\hline Jumlah & 26 & 51 & 23 & 100 \\
\hline
\end{tabular}

Ket: Tingkat pendapatan $=$ Rendah $(<\mathrm{Rp} 11$ juta per musim); Sedang (Rp 11 juta - Rp 32 Juta per musim); Tinggi ( $>$ Rp 32 juta per musim)

$$
\text { Nuraniputri (2015) dalam }
$$

penelitiannya menyatakan bahwa umumnya petani dengan pengalaman usahatani yang lebih lama, kurang menerapkan kegiatan budidaya yang intensif sehingga berdampak negatif terhadap produksi dan secara langsung berdampak pula terhadap pendapatannya.
Tabel 5. Tabulasi Silang Karakteristik Petani Berdasarkan Luas Lahan terhadap Kategori Tingkat Pendapatan

\begin{tabular}{lcccc}
\hline \multirow{2}{*}{$\begin{array}{c}\text { Kategori Luas } \\
\text { Lahan }\end{array}$} & \multicolumn{3}{c}{ Kategori Tingkat } & Pendapatan \\
\cline { 2 - 4 } & $\begin{array}{c}\text { Rendah } \\
(\%)\end{array}$ & $\begin{array}{c}\text { Sedang } \\
(\%)\end{array}$ & $\begin{array}{c}\text { Tinggi } \\
(\%)\end{array}$ & $(\%)$ \\
\hline Sempit & 16 & 8 & 0 & 24 \\
Sedang & 10 & 43 & 13 & 66 \\
Luas & 0 & 0 & 10 & 10 \\
\hline \multicolumn{1}{c}{ Jumlah } & 26 & 51 & 23 & 100 \\
\hline
\end{tabular}

Ket: Tingkat pendapatan $=$ Rendah $(<\mathrm{Rp} 11$ juta per musim); Sedang (Rp 11 juta - Rp 32 Juta per musim); Tinggi ( $>$ Rp 32 juta per musim)

Hubungan antara luas lahan dengan pendapatan bahwa luas lahan berpengaruh positif terhadap pendapatan atau penghasilan petani. (Astari dkk., 2016), maka perlunya melihat keterkaitan antara luas lahan yang dimiliki dengan pendapatan petani mitra. Sesuai dengan pernyataan Astari, pada faktanya data menyatakan bahwa seluruh petani dengan kategori lahan yang luas ada pada kategori pendapatan tertinggi yaitu di atas Rp 32.000.000, lalu mayoritas petani dengan lahan sedang memiliki tingkat pendapatan antara Rp 11.000.000 - Rp 32.000.000, begitu pun dengan petani berlahan sempit mayoritas pada kategori pendapatan di bawah Rp 11.000.000 (Tabel 5).

Nasution (2008) dalam penelitian berjudul "Pengaruh Modal Kerja, Luas Lahan, dan Tenaga Kerja Terhadap Pendapatan Usahatani Nanas (Studi Kasus: Desa Purba Tua Baru, Kec. 
Silimakuta, Kab. Simalungun)” menunjukkan bahwa luas lahan yang bertambah akan dapat meningkatkan hasil produksi yang berkaitan dengan peningkatan jumlah pendapatan yang diperoleh petani.

Tabel 6. Tabulasi Silang Karakteristik Petani Berdasarkan Produktivitas Mangga per Pohon terhadap Kategori Tingkat Pendapatan

\begin{tabular}{ccccc}
\hline \multirow{2}{*}{$\begin{array}{c}\text { Produktivitas } \\
\text { Manga (Kg per } \\
\text { Pohon) }\end{array}$} & \multicolumn{3}{c}{ Kategori Tingkat } \\
\cline { 2 - 4 } & $\begin{array}{c}\text { Rendah } \\
(\%)\end{array}$ & $\begin{array}{c}\text { Sedang } \\
(\%)\end{array}$ & $\begin{array}{c}\text { Tinggi } \\
(\%)\end{array}$ & Jumlah \\
\hline$<50$ & 21 & 36 & 5 & 62 \\
$51-100$ & 5 & 15 & 15 & 35 \\
$>100$ & 0 & 0 & 3 & 3 \\
\hline \multicolumn{1}{c}{ Jumlah } & 26 & 51 & 23 & 100 \\
\hline
\end{tabular}

Ket: Tingkat pendapatan $=$ Rendah $(<$ Rp 11 juta per musim); Sedang (Rp 11 juta - Rp 32 Juta per musim); Tinggi ( $>$ Rp 32 juta per musim)

Produktivitas per pohon tentu akan sangat menentukan pendapatan petani, hal ini bergantung kepada proses pemeliharaan dan kualitas pohon yang petani miliki (Supriatna, 2007), maka dengan adanya tabulasi silang diatas adalah untuk melihat bagaimana keterkaitan antar produktivitas per pohon dan tingkat pendapatannya. Mayoritas petani memproduksi sekitar $50 \mathrm{~kg}$ per pohon, dengan jumlah produktivitas pohon tersebut, mayoritas petani mampu menghasilkan pendapatan direntang $\mathrm{Rp}$ 11.000.000 - Rp 32.000.000. Semakin tinggi angka produktivitas mangga, pendapatan petani cenderung meningkat, seperti petani yang memiliki pohon yang mampu menghasilkan lebih dari $100 \mathrm{~kg}$ per pohonnya, berada pada kategori pendapatan tertinggi yaitu di atas $\mathrm{Rp}$ 32.000.000 (Tabel 6).

Hal ini sesuai dengan penelitian Anniroh (2006) yang menyatakan bahwa jumlah produksi berpengaruh nyata terhadap pendapatan. Jumlah produksi dalam usahatani jeruk siam berpengaruh secara nyata terhadap pendapatan dan pengaruhnya yaitu positif sehingga akan meningkatkan pendapatan.

\section{Hubungan Kemitraan dengan Pendapatan Petani Mangga}

Setiap petani memiliki persepsi yang berbeda dalam menilai kemitraan yang dilaksanakan. Petani dapat menganggap hanya beberapa aspek yang terbantu oleh kemitraan. Penilaian kemitraan ditentukan dari aspek manajemen kemitraan dan aspek manfaat kemitraan. Salah satu tujuan kemitraan pada dasarnya adalah untuk meningkatkan pendapatan kelompok mitranya melalui kerjasama yang sifatnya saling menguntungkan. Keberhasilan sebuah kemitraan dalam meraih tujuannya ditentukan dengan performa setiap aspek-aspek yang ada, maka dari itu perlu ditinjau keterkaitan antara 
aspek-aspek kemitraan dengan pendapatan petaninya sebagai kelompok mitra. Hasil di lapangan menunjukkan bahwa hampir seluruh petani memiliki persepsi yang sama terhadap hampir seluruh aspek kemitraan. Adapun aspek kemitraan yang memiliki perbedaan persepsi antar petaninya yaitu aspek kelengkapan perencanaan, ketergantungan penentuan harga, peningkatan pendapatan, jaminan harga, mutu dan penguasaan teknologi.

Tabel 7. Tabulasi Silang Aspek Kemitraan Berdasarkan Kelengkapan Perencanaan Kemitraan terhadap Kategori Tingkat Pendapatan

\begin{tabular}{ccccc}
\hline \multirow{2}{*}{$\begin{array}{c}\text { Kelengkapan } \\
\text { Perencanaan } \\
\text { Kemitraan }\end{array}$} & \multicolumn{4}{c}{ Kategori Tingkat } \\
\cline { 2 - 5 } & $\begin{array}{c}\text { Rendah Sedapatan } \\
(\%)\end{array}$ & $\begin{array}{c}\text { Sedang Tinggi } \\
(\%)\end{array}$ & $\begin{array}{c}\text { Jumla } \\
(\%)\end{array}$ \\
\hline $\begin{array}{l}\text { Meliputi Empat } \\
\text { Aspek }\end{array}$ & 8 & 23 & 15 & 46 \\
$\begin{array}{l}\text { Meliputi Lima } \\
\text { Aspek }\end{array}$ & 18 & 28 & 8 & 54 \\
\hline Jumlah & 26 & 51 & 23 & 10 \\
\hline
\end{tabular}

Ket: Tingkat pendapatan $=$ Rendah $(<\mathrm{Rp} 11$ juta per musim); Sedang (Rp 11 juta - Rp 32 Juta per musim); Tinggi ( $>$ Rp 32 juta per musim)

Semakin besar pendapatan petani, semakin petani sadar akan aspek-aspek yang tertulis dalam ketentuan kesepakatan dalam lingkup perencanaan kemitraan. UD Wulan Jaya mengatakan bahwa aspek-aspek yang termasuk dalam perencanaan meliputi lima aspek yaitu pemasaran, pembinaan teknologi, bimbingan, sarana produksi budidaya dan prasarana pertanian (Tabel 7). Hal ini dapat disebabkan petani yang memiliki tingkat pendapatan lebih besar cenderung sadar akan apa yang diberikan sepenuhnya oleh perusahaan, hal yang mungkin tidak disadari adalah adanya kebun percobaan sebagai prasarana pertanian yang disediakan oleh perusahaan. Petani yang memiliki pendapatan yang besar memang seringkali memanfaatkan kebun percobaan yang diberikan oleh perusahaan yang sebenarnya untuk digunakan secara bersama-sama.

Semakin besar tingkat pendapatan petani, petani meyakini bahwa penentuan harga memang ditentukan oleh pihak perusahaan dengan diketahui oleh pembina atau koordinator bagian petani mitra (Tabel 8). Adanya perbedaan pendapat terkait ketergantungan penentuan harga disebabkan oleh tidak adanya konfirmasi dari petani ke koordinator, sebagaimana petani lainnya lakukan agar dapat menyesuaikan perencanaan biaya permodalan untuk tahun berikutnya. 
Tabel 8. Tabulasi Silang Aspek Kemitraan Berdasarkan Kelengkapan Perencanaan Kemitraan terhadap Kategori Tingkat Pendapatan

\begin{tabular}{lcccc}
\hline \multirow{5}{*}{$\begin{array}{c}\text { Ketergantungan } \\
\text { Penentuan } \\
\text { Harga }\end{array}$} & \multicolumn{4}{c}{ Kategori Tingkat } \\
\cline { 2 - 4 } & $\begin{array}{c}\text { Rendah } \\
(\%)\end{array}$ & $\begin{array}{c}\text { Sedang } \\
(\%)\end{array}$ & $\begin{array}{c}\text { Tinggi } \\
(\%)\end{array}$ & $\begin{array}{c}\text { Jomlah } \\
(\%)\end{array}$ \\
\hline $\begin{array}{l}\text { Ditentukan } \\
\begin{array}{l}\text { Perusahaan } \\
\text { Mitra tanpa } \\
\text { melibatkan }\end{array}\end{array}$ & 3 & 5 & 8 & 16 \\
$\begin{array}{l}\text { Pembina } \\
\text { Ditentukan }\end{array}$ & & & & \\
$\begin{array}{l}\text { Perusahaan } \\
\text { Mitra dan } \\
\text { diketahui }\end{array}$ & 23 & 46 & 15 & 84 \\
Pembina & & & & \\
\hline \multicolumn{1}{c}{ Jumlah } & 26 & 51 & 23 & 100 \\
\hline
\end{tabular}

Ket: Tingkat pendapatan $=$ Rendah $(<\mathrm{Rp} 11$ juta per musim); Sedang (Rp 11 juta $-\mathrm{Rp} 32$ Juta per musim); Tinggi ( $>$ Rp 32 juta per musim)

Tabel 9. Tabulasi Silang Aspek Kemitraan Berdasarkan Persepsi Pendapatan terhadap Kategori Tingkat Pendapatan

\begin{tabular}{ccccc}
\hline \multirow{2}{*}{$\begin{array}{c}\text { Persepsi } \\
\text { Pendapatan }\end{array}$} & \multicolumn{3}{c}{ Kategori Tingkat } & Jendapatan \\
\cline { 2 - 4 } & $\begin{array}{c}\text { Rendah } \\
(\%)\end{array}$ & $\begin{array}{c}\text { Sedang } \\
(\%)\end{array}$ & $\begin{array}{c}\text { Tinggi } \\
(\%)\end{array}$ & $(\%)$ \\
\hline $\begin{array}{l}\text { Pendapatan } \\
\text { Tetap }\end{array}$ & 0 & 2 & 3 & 5 \\
$\begin{array}{l}\text { Pendapatan } \\
\text { Meningkat }\end{array}$ & 26 & 49 & 20 & 95 \\
\hline Jumlah & 26 & 51 & 23 & 100 \\
\hline
\end{tabular}

Ket: Tingkat pendapatan $=$ Rendah $(<\mathrm{Rp} 11$ juta per musim); Sedang (Rp 11 juta - Rp 32 Juta per musim); Tinggi ( $>$ Rp 32 juta per musim)

Petani dengan tingkat pendapatan diantara Rp 11.000.000 - Rp 32.000.000 hampir seluruhnya merasa bahwa kemitraan yang dilaksanakan memberikan peningkatan terhadap pendapatannya sebagai petani mangga (Tabel 9). Persepsi petani diyakinkan dengan program kemitraan yang menjamin harga dan akses pasar juga dengan bantuan lainnya, sehingga petani optimis bahwa kemitraan yang dilaksanakan akan memberikan dampak peningkatan pendapatan yang signifikan untuk kedepannya. Merujuk pada hasil penelitian Rachmah dkk. (2019), kemitraan merupakan salah satu instrument untuk meningkatkan keberlajutan usatani mangga.

Tabel 10. Tabulasi Silang Aspek Kemitraan Berdasarkan Jaminan Harga Kemitraan terhadap Kategori Tingkat Pendapatan

\begin{tabular}{|c|c|c|c|c|}
\hline \multirow{3}{*}{$\begin{array}{c}\text { Jaminan Harga } \\
\text { Kemitraan }\end{array}$} & \multirow{2}{*}{\multicolumn{3}{|c|}{$\begin{array}{l}\text { Kategori Tingkat } \\
\text { Pendapatan }\end{array}$}} & \multirow{3}{*}{$\begin{array}{c}\text { Jumlah } \\
(\%)\end{array}$} \\
\hline & & & & \\
\hline & $\begin{array}{l}\text { Rendah } \\
(\%)\end{array}$ & $\begin{array}{c}\text { Sedang } \\
(\%)\end{array}$ & $\begin{array}{l}\text { Tinggi } \\
(\%)\end{array}$ & \\
\hline $\begin{array}{l}\text { Lebih } \\
\text { rendah dari } \\
\text { Pasar }\end{array}$ & 0 & 3 & 0 & 3 \\
\hline $\begin{array}{l}\text { Sama } \\
\text { dengan } \\
\text { Pasar }\end{array}$ & 26 & 48 & 23 & 97 \\
\hline Jumlah & 26 & 51 & 23 & 100 \\
\hline $\begin{aligned} & \text { Ket: } \text { Tingkat p } \\
& \text { per musin } \\
& \text { Juta per } \\
& \text { musim) }\end{aligned}$ & $\begin{array}{l}\text { endapatar } \\
\text { n); Sedar } \\
\text { nusim); }\end{array}$ & $\begin{array}{l}\text { a Ren } \\
\text { hg }(\mathrm{Rp} \\
\text { Tinggi }\end{array}$ & $\begin{array}{r}\text { h }(<\mathrm{R} \\
\text { juta } \\
\text { Rp } 32\end{array}$ & $\begin{array}{l}11 \text { juta } \\
\text { Rp } 32 \\
\text { uta per }\end{array}$ \\
\hline
\end{tabular}

Semakin besar pendapatan petani semakin petani meyakini bahwa harga yang ditentukan ialah harga yang sama dengan pasar (Tabel 10). Harga yang sama dengan pasar bukan berarti harga tersebut lebih rendah atau pun bersifat merugikan. Harga pasar yang diambil adalah harga rata-rata tertinggi dari pasar yang bisa perusahaan mitra tawarkan kepada petani, baik itu harga dari ritel 
modern

maupun

supermarket.

Sebenarnya di luar hal tersebut, ada keuntungan-keuntungan yang didapatkan petani, diantaranya jaminan pemasaran. Selain itu, menurut Azizah dkk. (2019), petani yang bermitra tidak perlu repotrepot melakukan proses-proses pascapanen seperti mencuci dan sortasi.

\begin{tabular}{|c|c|c|c|c|}
\hline Ibel 11. & $\begin{array}{l}\text { Tabulasi S } \\
\text { Berdasarka } \\
\text { terhadap } \\
\text { Pendapata }\end{array}$ & $\begin{array}{r}\text { ang } \mathrm{A} \\
\mathrm{M} \\
\text { Kateg }\end{array}$ & $\begin{array}{l}\text { ek } \\
\text { u } \\
\text { ri }\end{array}$ & roduksi \\
\hline \multirow{2}{*}{$\begin{array}{c}\text { Mutu } \\
\text { Produksi }\end{array}$} & \multicolumn{3}{|c|}{$\begin{array}{c}\text { Kategori Tingkat } \\
\text { Pendapatan }\end{array}$} & \multirow{2}{*}{$\begin{array}{c}\text { Jumlah } \\
(\%)\end{array}$} \\
\hline & $\begin{array}{l}\text { Rendah } \\
(\%)\end{array}$ & $\begin{array}{l}\text { Sedang } \\
(\%)\end{array}$ & $\begin{array}{c}\text { Tinggi } \\
(\%)\end{array}$ & \\
\hline $\begin{array}{l}\text { Sama } \\
\text { dengan } \\
\text { sebelum } \\
\text { bermitra }\end{array}$ & 0 & 2 & 3 & 5 \\
\hline $\begin{array}{l}\text { Lebih baik } \\
\text { setelah } \\
\text { bermitra }\end{array}$ & 26 & 49 & 20 & 95 \\
\hline Jumlah & 26 & 51 & 23 & 100 \\
\hline
\end{tabular}

Ket: Tingkat pendapatan $=$ Rendah $(<\mathrm{Rp} 11$ juta per musim); Sedang (Rp 11 juta - Rp 32 Juta per musim); Tinggi ( $>$ Rp 32 juta per musim)

Petani pada tingkat pendapatan sedang mengatakan bahwa mutu produksi dari kemitraan ini lebih baik dibandingkan dengan sebelum kemitraan (Tabel 11). Sama halnya dengan produktivitas bahwa petani cenderung lebih lama dalam kondisi sudah bermitra dan melakukan usahatani di luar mitra hanya sekitar enam bulan hingga satu tahun. Dalam kemitraan, petani haru mampu menjaga kualitas, kuantitas dan keberlanjutan produksinya. Jika hal itu tidak terpenuhi atau tidak bisa dipenuhi oleh petani mitra, maka kemitraan akan berhenti (Sari dkk., 2019).

Peningkatan produktivitas pertanian harus menjadi prioritas untuk mencapai perbaikan hasil yang berkelanjutan dan melibatkan peningkatan teknologi pertanian serta manajemen termasuk perbaikan perairan tanah dan pengelolaan pasca panen (Al-Haboby et al, 2016).

Tabel 12. Tabulasi Silang Aspek Kemitraan Berdasarkan Penguasaan Teknologi terhadap Kategori Tingkat Pendapatan

\begin{tabular}{|c|c|c|c|c|}
\hline \multirow{2}{*}{$\begin{array}{c}\text { Penguasaan } \\
\text { Teknologi }\end{array}$} & \multicolumn{3}{|c|}{$\begin{array}{c}\text { Kategori Tingkat } \\
\text { Pendanatan }\end{array}$} & \multirow{2}{*}{$\begin{array}{c}\text { Jumlah } \\
(\%)\end{array}$} \\
\hline & $\begin{array}{c}\text { Rendah } \\
(\%)\end{array}$ & $\begin{array}{l}\text { Sedang } \\
(\%)\end{array}$ & $\begin{array}{l}\text { Tinggi } \\
(\%)\end{array}$ & \\
\hline $\begin{array}{l}\text { Sama } \\
\text { dengan } \\
\text { sebelum } \\
\text { bermitra }\end{array}$ & 0 & 2 & 3 & 5 \\
\hline $\begin{array}{l}\text { Lebih baik } \\
\text { setelah } \\
\text { bermitra }\end{array}$ & 26 & 49 & 20 & 95 \\
\hline Jumlah & 26 & 51 & 23 & 100 \\
\hline \multicolumn{5}{|c|}{$\begin{array}{l}\text { Ket: } \text { Tingkat pendapatan }=\text { Rendah }(<\text { Rp } 11 \text { juta } \\
\text { per musim); Sedang }(\text { Rp } 11 \text { juta }- \text { Rp } 32 \\
\text { Juta per musim); Tinggi }(>\text { Rp } 32 \text { juta per } \\
\text { musim) }\end{array}$} \\
\hline
\end{tabular}

Menurut Haboby et al (2016), perbaikan hasil yang berkelanjutan akan berdampak terhadap peningkatan pendapatan petani seiring dengan peningkatan produktivitasnya, dimana peningkatan produktivitas dipengaruhi dengan peningkatan kemampuan penggunaan teknologi dan teknologi itu 
sendiri sehingga akan berbanding lurus dengan pendapatan yang dihasilkan oleh petani. Merujuk pada Saefudin dkk. (2019), petani mangga dengan penguasaan teknologi yang baik akan bertahan dan dapat mengembangkan usahatani mangganya. Namun demikian, hal ini kurang sesuai dengan keadaan petani responden dimana data menyatakan bahwa penguasaan teknologi dirasa memang tidak sesignifikan itu berhubungan langsung dengan pendapatan. Hanya sedikit petani dengan pendapatan $\mathrm{Rp} \quad 11.000 .000 \quad-\mathrm{Rp}$ 32.000.000 menganggap bahwa penguasaan teknologi dalam kemitraan dirasa meningkat dari sebelumnya (Tabel 12).

\section{KESIMPULAN DAN SARAN}

Karakteristik petani yang
cenderung berhubungan dengan
pendapatan petani adalah usia, lama
pengalaman bertani, luas lahan dan
produktivitas per pohon. Sementara,
aspek kemitraan cenderung berhubungan
dengan pendapatan petani mangga adalah
kelengkapan perencanaan,
ketergantungan penentuan harga,
peningkatan pendapatan, jaminan harga,
mutu hasil produksi, dan penguasaan
teknologi.

Pihak perusahaan, khususnya divisi pengelola program kemitraan melakukan upaya untuk menjaga kepercayaan petani mengenai ketentuan penetapan harga dan pemberian fasilitas input produksi yang dirasa menjadi jaminan khusus bagi petani, sehingga petani tetap berkeinginan menjalin mitra untuk jangka panjang.

\section{DAFTAR PUSTAKA}

Al-Haboby, A., Breisinger, C., Debowicz, D., El-Hakim, A. H., Ferguson, J., Telleria, R., \& Van Rheenen, T. (2016). The role of agriculture for economic development and gender in Iraq: a computable general equilibrium model approach. The Journal of Developing Areas, 50(2), 431-451.

Anniroh, F. 2006. Efisiensi Biaya dan Pendapatan Usahatani Petani Jeruk Siam (Studi Kasus di Desa Semboro Kecamatan Semboro Kabupaten Jember). Skripsi. Jember: Jurusan Sosial Ekonomi Pertanian Universitas Jember.

Astari, N. N. T., \& Setiawina, N. D. (2016). Pengaruh luas lahan, tenaga kerja dan pelatihan melalui produksi sebagai variabel intervening terhadap pendapatan petani asparagus di Desa Pelaga Kecamatan Petang Kabupaten Badung. J. Ekonomi dan Bisnis Universitas Udayana, 5(7), 22112230.

Azizah, M. N., Rasmikayati, E., \& Saefudin, B. R. (2019). Perilaku budidaya petani mangga dikaitkan dengan lembaga pemasarannya di Kecamatan Greged Kabupaten Cirebon. Jurnal Ilmiah Mahasiswa 
Agroinfo Galuh, 5(1), 987-998. DOI:

http://dx.doi.org/10.25157/jimag.v5 i1.1447.

Barrett, C. B., Bachke, M. E., Bellemare, M. F., Michelson, H. C., Narayanan, S., \& Walker, T. F. (2012). Smallholder participation in contract farming: comparative evidence from five countries. World Development, 40(4), 715730.

BPS [Badan Pusat Statistik]. (2007). Indikator Kesejahteraan Rakyat. Badan Pusat Statistik. Jakarta.

Hafsah, M. J. (1999). Kemitraan Usaha: Konsepsi dan Strategi. Pustaka Sinar Harapan.

Nasution, R. (2008). Pengaruh Modal Kerja, Luas Lahan, Dan Tenaga Kerja Terhadap Pendapatan Usahatani Nenas (Studi Kasus: Desa Purba Tua Baru, Kec. Silimakuta, Kab. Simalungun).

Nuraniputri, U. 2015. Analisis Produksi, Pendapatan Usahatani dan Pemasaran Manggis di Kabupaten Sukabumi. Tesis. Bogor: Sekolah Pascasarjana Institut Pertanian Bogor.

Rachmah, A. D., Rasmikayati, E., \& Saefudin, B. R. (2019). Factors related to continuation of mango cultivation. Jurnal Pertanian, 10(2), 52-60. DOI: http://dx.doi.org/10.30997/jp.v10i2. 1864.

Rasmikayati, E., \& Saefudin, B. R. (2018). Analisis Faktor-Faktor Yang Mampu Mendorong Petani Mangga Untuk Meningkatkan Perilaku Agribisnisnya Pada Era Globalisasi. Paradigma Agribisnis, 1(1), 1-13. DOI: http://dx.doi.org/10.33603/jpa.v1il. 1491.

Rasmikayati, E., Arisyi, Y. H., Saefudin, B. R., \& Awaliyah, F. (2020). Studi
Pola dan Derajat Kemitraan Pemasaran Mangga antara Petani Mangga dengan UD Wulan Jaya. AGRIFOR, 19(1), 45-58. DOI: https://doi.org/10.31293/af.v19i1.4 567.

Rasmikayati, E., Kusumo, R. A. B., Sukayat, Y., Arisyi, Y. H., \& Saefudin, B. R. (2020). Karakteristik Individu Dan Usahatani Petani Mangga Yang Melakukan Kemitraan Pemasaran Di Kecamatan Sindangkasih Kabupaten Majalengka. Paradigma Agribisnis, 3(1), 12-23. DOI: http://dx.doi.org/10.33603/.v3i1.35 44.

Rasmikayati, E., Setiawan, I., \& Saefudin, B. R. (2017). Kajian Karakteristik, Perilaku Dan Faktor Pendorong Petani Muda Terlibat Dalam Agribisnis Pada Era Pasar Global. Mimbar Agribisnis: Jurnal Pemikiran Masyarakat Ilmiah Berwawasan Agribisnis, 3(2), 134149.

DOI: http://dx.doi.org/10.25157/ma.v3i2. 565.

Saefudin, B. R., Rasmikayati, E., Dwirayani, D., Awaliyah, F., \& Rachmah, A. R. A. (2020). Fenomena Peralihan Usahatani Mangga Ke Padi Di Kecamatan Sedong, Kabupaten Cirebon, Jawa Barat. Paradigma Agribisnis, 2(2). DOI:

http://dx.doi.org/10.33603/jpa.v2i2. 3156.

Sari, A. F., Rasmikayati, E., \& Saefudin, B. R. (2019). Behavioral Dynamics of Farmers and First Buyer in Marketing Mangoes in Sedong District, Cirebon Regency, West Java. Agrifor, 18(1), 63-72. DOI: https://doi.org/10.31293/af.v18i1.4 072.

Solihahani, E., Zulan, F. A., Inayatin, N., Susanti, N., \& Zuniana, Q. (2014). 
Agribisnis Tembakau Besuki NaOogst: Tinjauan Ekonomi Pertanian. Malang: Surya Pena Gemilang.

Supriatna, A. (2007). Kajian Kelayakan Usahatani dan Marjin Tataniaga Mangga (Mangifera Indica)(Studi Kasus Di Kabupaten Majalengka, Jawa Barat). Jurnal Pengkajian dan
Pengembangan

Teknologi Pertanian Vol, 10(2), 166-178.

Suratiyah, K. (2015). Ilmu Usahatani: Edisi Revisi. Jakarta: Penebar Swadaya. 